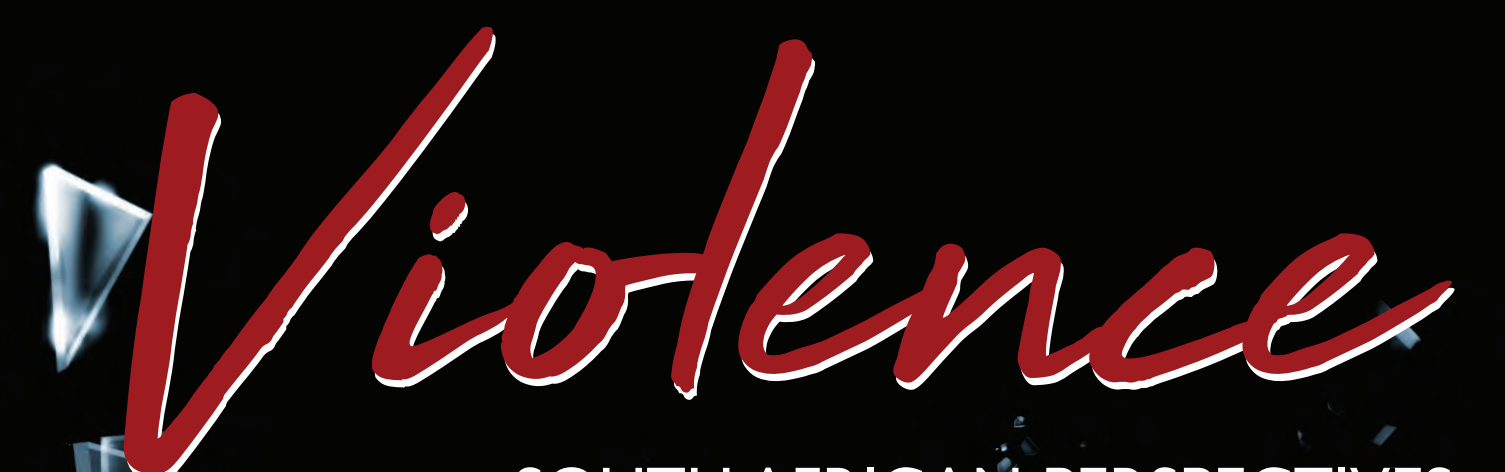

SOUTH,AFRICAN PERSPECTIVES

$\rightarrow$

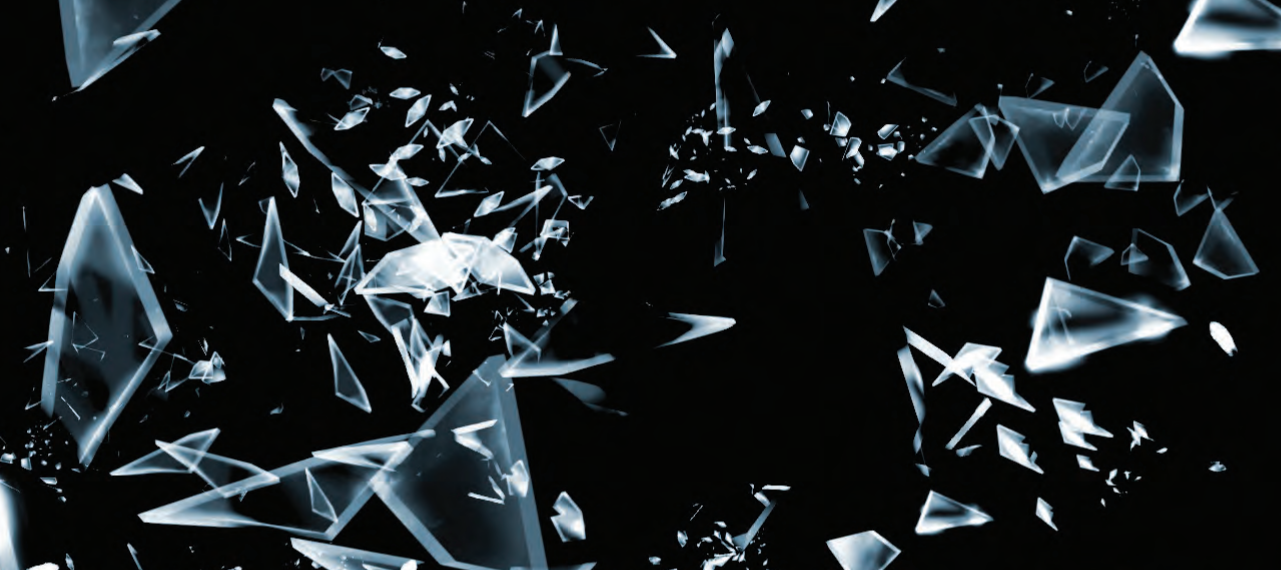

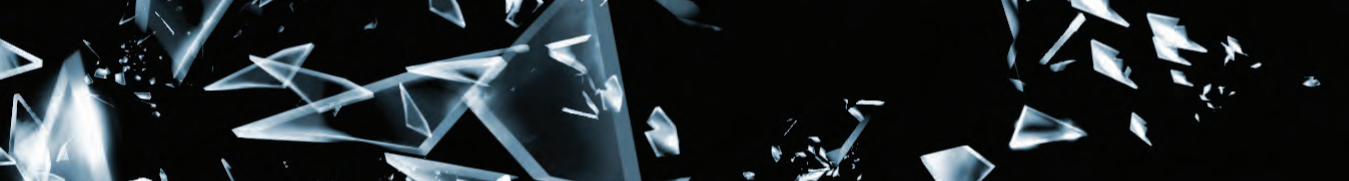

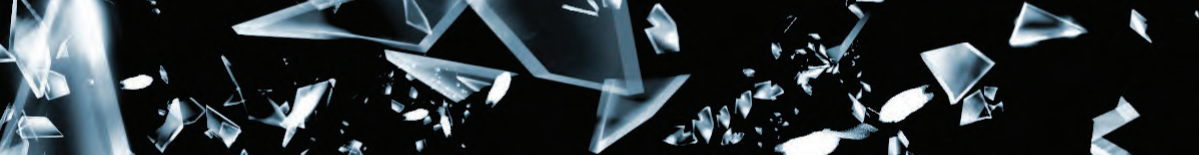

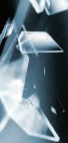

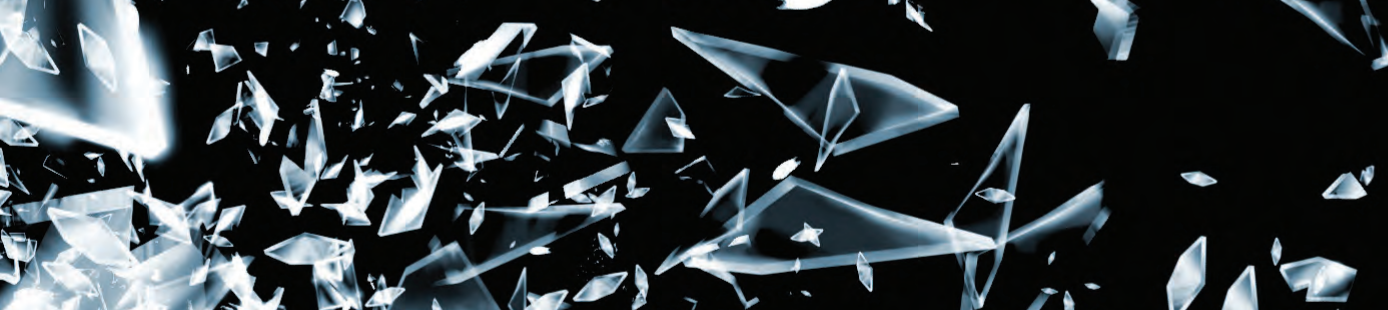

,

a 4 < 6

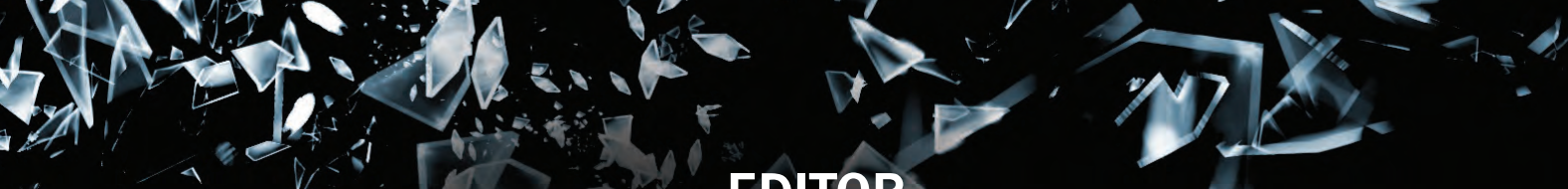

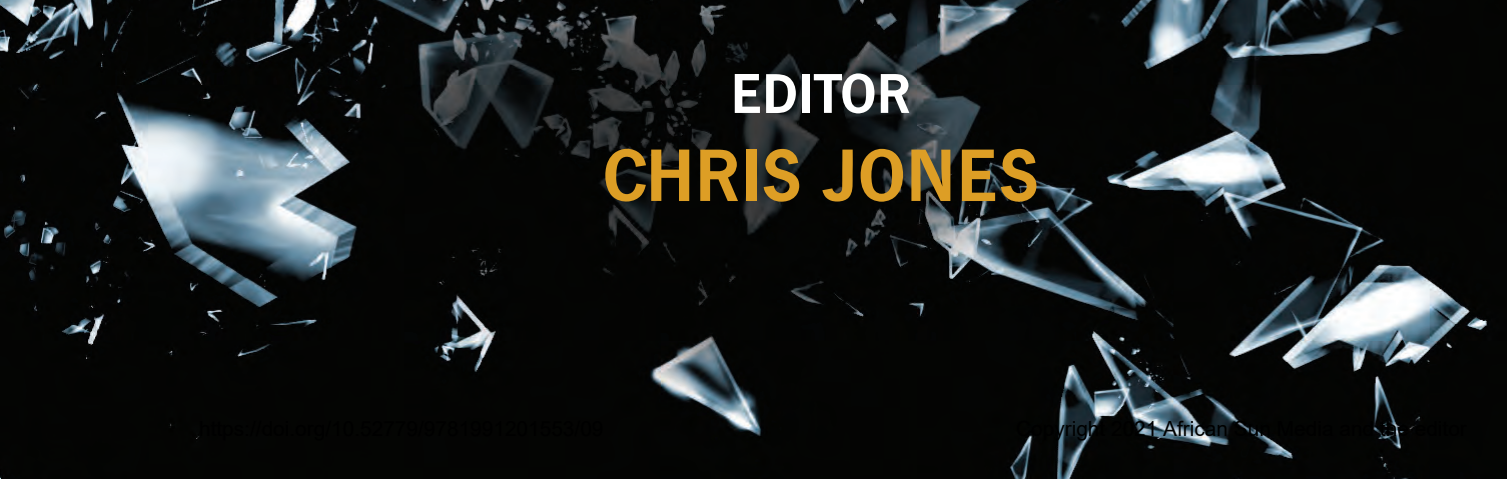




\title{
VIOLENCE OF CORRUPTION IN THE SOUTH AFRICAN PUBLIC SECTOR
}

Sakhile Zondi

\begin{abstract}
"Corruption violates the rule of law, and the rule of law is the prerequisite for the protection of human rights. If there is no rule of law, there is no protection of human rights."

(Institute for Security Studies [ISS], 2010)
\end{abstract}

\section{Keywords}

corruption; ethical leadership; good governance; public sector; service delivery; violence

\section{INTRODUCTION}

In light of the increasing awareness of the detrimental effects of corruption on development, strategies to fight it are now a top priority in policy circles. Yet, in many countries ridden with systemic corruption, few successes have resulted from these strategies. It is also important to stress from the onset that the phenomenon of corruption is a universal problem (Myint 2000; Mafunisa 2007:263; Ruhiiga 2009:1095; Soliman \& Cable 2011:735) and considered stubbornly entrenched in the less developed nations, particularly in the Sub-Saharan African Region. The increasing public concern over corruption has resulted in a large amount of scholarly research on this subject. The scholars are of the opinion that corruption has become one of the world's biggest concerns that affect efforts for global sustainable development, human rights, peace and security, access to decent healthcare, education, and the legitimacy of government institutions (Feathers 2014:290).

Furthermore, corruption in all its forms is viewed as a crime against humanity. Authors from diverse academic backgrounds postulate corruption as an act that poses a threat to social peace and security. It also has debilitating effects on the lives of billions of people around the world, and usually it is the most vulnerable citizens that are the hardest hit by the consequences of corruption (Ganahl 2017:8). The perception of corruption undermines public trust in the government's intentions and its ability to protect citizens and provide them with basic services. In both public and private sector institutions where corrupt activities are enacted, corruption is morally unacceptable and a legally unwarranted act that adversely affect socio-economic development endeavours for poor citizens. "This is certainly the case in South Africa. The country's 
media [sources] are replete with reports of corruption at all levels of government, and there's growing evidence that corruption has resulted in the ineffective use of state resources aimed at providing essential services" (Mantzaris 2017:n.p).

What are the reasons for this disappointing state of affairs? Prempeh and Kwasi (2008) observe that for the most part, Africa's current desperate situation has been attributed to three causes. First and foremost, they observe moral decay and incorrigibly selfserving greed, along with failure to implement good governance to be at the heart of corrupt activities across the world. Second, ethical leadership in the public and private sectors, non-profit and charity organisations has been overtaken by unaccountable and predatory governance systems which lack vision and passion for creating better living conditions for poor communities. Third, public sector corruption is politicised and involves high profile government officials whose corrupt activities are not investigated with zeal and rigour.

Anti-corruption initiatives and good governance are the top agendas today; more oversight mechanisms and resources have been channelled to various stakeholders during the last two decades in support of the anti-corruption and good governance agenda. For example, The Sustainable Development Goals (SDG) agenda advanced by the United Nations (UN) comprises 17 goals that are initiated to protect global communities and improve their socio-economic conditions (Voegtlin \& Scherer 2017:13). One of these goals, Goal 16, is set to curb public sector corruption and deviant activities. "The gravity of this imperative is undeniable given the recent sobering observation that more than $80 \%$ of the world's population lives in a country with a serious corruption problem" (Transparency International 2014).

Similarly, The Organisation for Economic Development and Co-operation (OECD 2018:7) responds to the repeated global call to coordinate anti-corruption and integrity initiatives in both developed and developing nations. This includes the mandate to adopt a more coherent approach to better coordinate anti-corruption programmes so as to improve standards of living in poor nations (OECD 2018:7). Despite the existence of these anti-corruption initiatives/programmes, tangible outcomes on the ground have been far from encouraging.

\section{CONCEPTUALISATION OF CORRUPTION}

What is corruption? For the purpose of this chapter, it is necessary to unpack the concept of 'corruption' in order to give context to various unconstitutional and unethical practices that engulf the South African public sector. The concept of corruption is a multifaceted phenomenon and contains too many connotations. The forms of corruption are diverse in terms of who the initiators and beneficiaries are, how it is executed, and to what extent it is committed (Ames \& Fiske 2015:n.p.). In addition, the motivation and consequences for corruption are complex and diverse, 
and have been studied within the lenses of individual, cultural, economic, and organisational ethics (Collin 1998:215).

Different authors from different academic backgrounds concur that corruption is a household name in many developing and developed countries which has negative socio-economic implications on the lives of poor communities. In more general terms, corruption is a cancer that ravages political, cultural, social, religious, and economic fabrics of society and contribute to the malfunctioning of vital social organs (Amundsen 2013:8). Corrupt activities have negative impacts for the development outlook of many countries as they undermine good governance, distort public policy, and lead to the misallocation of scarce resources and derange the quality of life (Transparency International 2014).

Corruption as an activity has been a bone of contention and a subject of substantial amount of overtheorising for over 50 years, and this has produced large amounts of puzzling explanations, typologies, and interventions. It involves a number of unconstitutional activities, ranging from paying a bribe to public servants in return for personal favours to a wide range of dubious economic gains in which politicians enrich themselves (Transparency International 2014). The concept of corruption also refers to purposeful, non-compliance with rules that define acceptable social behaviours of the individual who occupy governance or leadership roles in society (Boris 2005:9). This view is further elaborated in Sobel and Garret (2002:115); that corruption is the intentional non-compliance with the arm's-length principle aimed at deriving some advantage for oneself or for related individuals from this behaviour.

Corruption is also conceptualised as an unconstitutionalised practice involving the offering, giving, receiving, or the direct and/or indirect solicitation of anything of value to influence improperly action of another party (Kempfer 2015:23). The definition in South Africa's Prevention and Combatting of Corrupt Activities, Act 12 of 2004, (PCCA) is broader and includes any 'gratification' that would induce either public or private actors to act in an improper manner in the performance of their duties (RSA 2004).

\section{FORMS OF CORRUPTION}

The literature alludes to the following forms of corruption as detrimental to the future of the public sector in both developing and developed nations.

\section{State capture corruption}

The concept of state capture has become a buzzword in contemporary South African communities. It was first used by the World Bank in 2000 to describe the situation that confronted central Asian countries during their political transitions in which few politicians exercise political powers to unfairly influence political decisions in order 
to cement their economic and political positions - the corruption associated with state capture. Grycar and Prenzler (2013:n.p.) opined that this type of corruption is linked to the manipulation of the established rules and regulations in order to favour interests of the corruptors. It is also a very pervasive form of state corruption involving tendencies of the most influential individuals or institutions to influence a country's legal processes, policies, and resources in order to enrich themselves.

In the case of South Africa, state capture refers to the way in which private individuals from a foreign country (Guptas) have seized government organs in order to redirect resources into their own hands (Gavisser 2018:255). In orchestrating state capture in South Africa, the influential individuals, public institutions, and companies were monopolised, including State Owned Enterprises (SOEs), cabinet ministers, and law enforcement agencies. The appointment of the Judicial Commission of Enquiry in January 2018 has been captioned as the 'truth and reconciliation of our time'. It aims to cleanse post-apartheid South Africa of its dark stains by exposing gross violations that occurred between 2009 and 2018 (Mail \& Guardian 2020:n.p.).

\section{Political corruption}

It occurs in the top levels of the government echelons. The assumptions behind this type of corruption are analytically clear as they focus on a wide range of corrupt activities that are committed by high profile politicians. In the definition shared by most authors, including the World Bank, political corruption is construed as transactions involving private, business, public, and civil society sectors in which collective goods are illegitimately converted into private gains (Heidenheimer 2009:15). Political corruption occurs at the high level of the political ladder where politicians abuse the political power they are armed with in order to enrich themselves at the expense of the poor communities (Touchton \& Wampler 2013:n.p.). This type of corruption does not only subvert the public resources, but also influence the manner in which political decisions are made (Amundsen 2013:12). Against this background, political corruption can be construed as the fundamental aspect that contributes to institutional decay which predominantly affects the South African public sector.

\section{Bureaucratic corruption}

The contributions of public bureaucracy in streamlining effective administration in contemporary societies cannot be underestimated. In South Africa, the performance of the three spheres of government and other public entities faces severe criticism due to the widening gap between the anticipated roles of public bureaucracy and actual outputs. In this context, public bureaucrats, including policymakers, public servants, and politicians are often blamed for engaging in corruption and contribute to inefficiencies that characterise many government institutions in Africa. Uslaner (2017:12) observes bureaucratic corruption as a critical challenge confronting the 
government sector and which slows down the pace of service delivery, particularly in the developing nations. South Africa today is a typical case of a country whose development initiatives and constitutional democracy have been severely paralysed by the threats of bureaucratic corruptions. Nwankwo, Ananti and Madubue (2015:n.p.) have concurred that the concept of bureaucratic corruption is associated with the illegal activities of bureaucrats. They added that, traditionally, the concept is used to denote the practices of buying favour from bureaucrats who formulate and implement government economic and political policies.

\section{THEORIES OF CORRUPTION}

Theories of corruption have been developed and improved with passage of time. The literature evidence suggests that there is no theory in this field that is completely irrelevant. In this section, the theories of corruption are discussed with the view to understand their contributions in curbing corruption. Against this background, deontology, consequentialism, and virtue theories are unpacked.

\section{Deontology theory and corruption}

Deontologists argue that corruption is a human act that has moral and ethical implications and as such it should be analysed from ethical and moral perspectives. Deontology theory was first used in a publication of Immanuel Kant in the 18th century (Watkins 2005). The word "deontology" originates from the Greek word deon for a lawful duty or obligation. Its fundamental thrust is to differentiate wrong from right. Kant believed that ethical actions are guided by the universal moral laws, such as don't lie, don't steal, don't cheat (Encyclopaedia of Applied Ethics 1998:n.p.).

The deontologist perspective seeks to understand individual moral duties by raising the question: 'What is my duty?' From a deontological perspective, law, duty, and obligations are the point of departure in deciding an individual criminal behaviour. This suggests that humans make moral decisions by determining what the law applies to the situation. The fundamental premise of deontology is that some actions are morally correct and should be done as long as they benefit the society. The theory emphasises obedience to rules consistent with universal moral laws regardless of circumstances. The rightness of an action is determined by its consequences, for example, it is purported that if some action genuinely brings about happiness in the world, it is a good action despite its consequences (Thomas 1995:n.p.).

\section{Theory of consequentialism}

Consequentialism is classified under normative and teleological theories, holding the view that consequences of one's actions are the basis of judgement of the rightness and wrongness (Thomas 1995:n.p.). Consequentialism is a direct opposite of deontology in which the focus of a conduct is judged by actions, not its consequences. 
Consequentialist approach makes decisions based on the consequences of outcomes of an action. The theory argues that the action is correct if it promotes the best consequences. The best consequences are those that yield happiness. This theory is premised on two approaches, namely, the utilitarianism approach developed by Jeremy Bentham (1748-1832) and the Egoism approach of Ayn Rand (1905-1982).

- Utilitarianism: The central view in this approach is "an act is right or wrong according to the values of its consequences", thus the end "justifies the means" and every act is judged by its results, not by its intrinsic value.

- Egoism: The view that individuals are motivated to pursue their own selfinterests, and no one is having obligations to promote one's interests.

\section{Virtue theory}

Virtue theory is an ethical theory developed by the Greece philosopher, Aristotle (384-322BC) to describe the manner in which individual ethical or acceptable behaviours is developed. From Virtue theorists' point of view, virtue is acquired through practice. Similarly, Cushman (2013) argues that the fundamental goal of life is eudanonia, implying 'happiness', 'well-being' or the 'good life'. Eudanonia is considered a goal that can be achieved through a lifetime of practising. The theory focuses mainly on the roles of societies to shape one's ethical conduct through his/her developing good character traits, such as kindness, respect, love, and generosity.

\section{UNPACKING THE VIOLENCE OF CORRUPTION IN SOUTH AFRICA}

Corruption in South Africa includes the embezzlement of public resources, private use of public resources, theft, bribery, and improper favouritism. In terms of global ratings, South Africa is ranked 61st out of 168 most corrupt countries in the world (Transparency International 2014). It also scored 45 points out of 100 on the 2016 Corruption Perceptions Index. The impacts of corruption are exemplified by increasing levels of poverty, unemployment, inequalities, and various socio-economic ills. It is generally accepted that there is no single explanation to the question why South Africa has higher levels of corruption than other African states. Many scholars on corruption studies support the perception that a number of factors have contributed to this situation. For example, Benson and Morrison (2014:n.p.) opine that corruption in the country does not only reflect bad morals and weak law enforcement, but rather is entrenched in two basic factors, namely class formation and systemic failures.

\section{Class formation}

Corruption is influenced by class formation, especially the formation of new black elites (Von Holdt 2019:n.p.). This implies that corruption in South Africa is partly influenced by political powers and privileges of the few minorities who control 
economic opportunities. The emergence of black elites is often a ferociously contested, ugly, and violent affair that has divided the nation and undermined the 1994 democratic gains. This narrative reflects recent events in the South African politics that involves two opposing groups. On the one hand, is the network of highprofile politicians, cabinet ministers, as well as the Gupta family which is centred on former President Zuma. This group is responsible for the engineering of state looting, state capture and self-enrichment (Von Holdt 2019:n.p.). On the opposing side, there are ethical politicians, business leaders and ordinary citizens who uphold constitutional values of the constitutional democracy, transparency, accountability, and the rule of law.

\section{Systemic failures}

The hopes for a new democratic South Africa that was attained in 1994 have been replaced by systemic failure which is evident with the failing economy, poor policy implementation, and high levels of illiteracy. The failure of democratic governance in South Africa is exemplified by the perpetuation of poverty, skewed policy decisions and the denial of poor communities to access basic social services (Cushman 2015:n.p.). According to the Country Corruption Assessment Report (2013), fraud, theft, and bribery are the common corrupt activities in the South African public sector. Some public sector institutions are highly affected in this regard, including the South African Police Services (SAPS), municipalities, public works, and the South African Social Security Agency (SASSA). According to Van der Merwe (2016:n.p.), the causes of these corrupt activities are identified as personal greed, poverty, poor checks and balances, and the lack of ethical conduct.

\section{FRAMEWORK FOR COMBATING PUBLIC SECTOR CORRUPTION}

The strength of political and socio-economic development of society depends on its capacity for good governance and the priority accorded on the creation of ethical leadership. Ethical leadership is also understood to have considerable benefits for both public and private sector organisations (Conrad 2013:77). The South African government has introduced various mechanisms to combat fraud and corruption in the public sector, however, in spite of these mechanisms, corruption still remains a critical challenge that plagues South African communities with deep socio-economic challenges. The promulgation of the legislative and policy framework and various control mechanisms have been a top priority of the government since 1994.

Berth and Bertok, cited in Uys (2012:6-8) suggest three key elements for the detection and elimination of corrupt activities for public sector organisations, especially within the context of the developing nations. These include guidance, control, and management elements. 
- Guidance: The guidance element of the framework comprises checks and balances mechanisms, such as the prioritisation of regulatory initiatives, enhancement of ethical conduct, ethical auditing, as well as the implementation of monitoring and evaluation (M\&E) systems.

- Controlling: The control element should strengthen the coordination mechanisms, such as legal and administrative law, a workable code of conduct, as well as enhanced accountability and social responsibility.

- Management: The management element includes education and training on good/ethical conduct, a choice between litigation versus ethical conduct, counselling on ethical matters, as well as the protection of whistle-blowers and implementation of institutional hotlines and helplines.

In addition to the abovementioned initiatives for the combating of criminal activities, the following strategies have been put in place to promote ethical conduct in the South African public sector context.

\section{Batho-Pele principles}

In 1997, the South African government promulgated the White Paper on the Transformation of Public Service Delivery which outlined eight Batho-Pele Principles that were later extended to 11 in 2008. Batho Pele Principles refer to a leadership approach that prioritises people's needs (RSA 1997). This approach also requires the involvement of the public in holding public service organisations accountable for the quality of services provided. It is anticipated that service delivery and community development may be revitalised through principles of consultation, redress, service standards, equal access to community services, open and transparent operations, curtesy, value for money, strategic leadership, innovation and excellence, as well as customer impact (Department of Public Service and Administration 2016).

\section{Legislative and policy framework}

The demise of the apartheid rule in 1994 paved the way for the democratic governance, which is established along the values of ethical leadership, integrity, and equal access to public services (Department of Public Service and Administration 2016). Many of the policies that were promulgated by the current governance system are oriented towards reversing the imbalances created during the apartheid rule, and are committed to curb corruption and promote clean governance at all government levels. The Constitution of 1996 is considered a supreme law of the country and a framework for policy formulation in the three spheres of government and other government institutes. The promulgation of the Prevention and combatting of Corrupt Activities Act 12 of 2004 serves as a regulator of ethical conduct and strengthens measures to combat corrupt related activities. 


\section{Public Service Commission}

The Public Service Commission (PSC) is an independent structure that is established as per the recommendations of Chapter 10 of the Constitution (RSA 1996) to establish an effective public administration that is open, transparent, and developmentoriented. Amongst the roles of the PSC is to eliminate corruption by enforcing control measures for good governance. The Constitution recommends the establishment of a single PSC consisting of 14 members who are referred to as "commissioners". The commissioners are based in the nine provinces of the country (Department of Public Service and Administration 2016). The PSC is accountable to the National Assembly and must report to it annually. It must also report to the Legislature of the province concerned on its activities in each province (RSA 1996).

The Commission plays an important role in safeguarding democratic values of the country and provides oversight mechanisms over public administration (Department of Public Service and Administration 2016). Sections 195 and 196 of the Constitution make provisions for the core values governing public administration which should be facilitated by the Commission, as well as power roles of the PSC. Accordingly, PSC is required to exercise its powers and roles without fear, favour, or prejudice (Department of Public Service and Administration 2016). Apart from the Constitution, the Public Service Act, 1997, defines roles and responsibilities on the commission in terms of the promotion of good governance and maximising service delivery impact throughout the country.

\section{Public Protector}

The Public Protector is an independent structure that is established by Chapter 9 of the Constitution (RSA 1996). The Public Protector is responsible for ensuring that public administration is an impartial institution that provides checks and balances and increase accountability of public institutions (Van der Waldt, Khalo, Nealer, Phutiagae, Van der Waldt, Van Niekerk \& Venter 2014:n.p.). This structure plays an important defence role against lawlessness, maladministration, and corruption.

The role of the Public Protector in promoting good governance cannot be underestimated. This view emanates from the central role it plays in guiding the formulation and implementation of public policies that are intended for the overall development of the country. Within the past four years, this structure has been dominating centre stage in the development discourse of the country due to challenges facing its functionality. Consequently, the Public Protector has been severely criticised due to its vague stance on public corruption and is blamed for the lack of consequence management for those officials who flout municipal financial management systems. 


\section{Auditor General}

The Auditor General of South Africa has a constitutional mandate and, as the Supreme Audit Institution (SAI) of South Africa, exists to strengthen the country's democracy by enabling oversight, ethical leadership, and good governance in the public sector through auditing, thereby building public confidence (Van der Waldt et al. 2014:n.p.).

The fundamental role of the Auditor General is to provide an independent review of the performance and accountability of the public sector institutions and report to Parliament. The Auditor General's Department aims to meet the needs and expectations of the Parliament, the executive, and citizens, as well as to add value to public sector performance and accountability. This independent review is thus performed to ensure the propriety, regularity, and compliance with all the statutory and other regulatory requirements and the economy, efficiency, and effectiveness of the operations (Van der Waldt et al. 2014:n.p.).

\section{RESEARCH METHODOLOGY AND FINDINGS}

The research methodology employed in the chapter is premised on specific paradigms of unobtrusive research techniques, including conceptual and document analysis. Unobtrusive research refers to methods of collecting data which does not interfere with the subjects under study (because these methods are not obtrusive). In the context of this chapter, unobtrusive research was necessary to collect data without interacting with the subjects (Maroveski 2016:n.p.). Data analysis is explored through an in-depth analysis of case studies that demonstrate the extent of corruption and lack of ethical conduct in the South African public sector context. In this regard, various sources of literature, including the Auditor General's reports, Transparency International, and the Corruption Perception Index were reviewed with the view to establish common forms of corruption in the South African context and their impacts on the country's development.

Unaccountability and failures to enforce an ethical code of conduct are the main challenges confronting the South African Government. Kuye and Mafunisa (2003:n.p.) opine that while the involvement of political executives (president, ministers, premiers, members of executive councils [MECs], councillors and mayors) in corrupt or questionable activities has drawn much public attention to the issue of political responsibility, the status of administrative responsibility has also become a matter of increasing anxiety (Kuye \& Mafunisa 2003:422). Worryingly, the findings of the 2018-2019 public sector audit released by the Auditor General confirmed that corruption is a major concern that hinders South Africa's economic development, and it tends to slow down the democratic process and stability in the country. The findings established that the index found that most of the municipalities in South Africa are in financial distress, lacking proper budget planning, and are not exercising adequate fiscal discipline with expenses exceeding income and resulting in losses. 
Accountability failures in the public sector have negative impacts on the lives of citizens (Auditor General's Report 2018-2019). Where there is no accountability, public institutions fail to meet their objectives. This in turn adversely affects the citizens who rely on those institutions for their service delivery. Corruption in public administration and in political decision-making processes is a major challenge to those who are dedicated to accountability, corruption free institutions and clean governance (Transparency International 2014).

\section{RECOMMENDATIONS AND WAY FORWARD}

There is a general view amongst various authors that corruption in the public sector has a negative impact on the development outlook of the country. This view is informed by recognition that corruption does not only derail development, but also that it affects poor communities who are denied opportunities to achieve their socioeconomic aspirations. The best international practices drawn from countries with strong reliance on the culture of ubuntu and good governance should be emulated in South Africa going forward. The literature evidence however suggests that public sector corruption can be minimised through the establishment of effective check and balance systems and the full implementation of anti-corruption policies.

To this end, the existing legislative framework and oversight mechanisms do not exercise their influence effectively due to political influence. Against this background, Manyaka and Nkuna (2014) suggest a need for strong political will to combating corruption. Measures to encourage the implementation of good governance across the public sector should be prioritised. This should also include the prioritisation of effective leadership that entrenches ethical conduct, professionalism, and passion for the development of the country.

\section{CONCLUSION}

This chapter has sought to outline ethical dilemmas that constitute corruption in the South African public sector. In light of corruption challenges in the public sector, the government has endeavoured to establish control mechanisms for enhancing good governance and prioritisation of service delivery to the poor. However, these mechanisms do not always yield positive results, due to their poor implementation. It is therefore imperative that the government revise its anti-crime strategies with the view to identify loopholes and devise solutions as a matter of urgency. 


\section{REFERENCES}

Ames, D.L. \& Fiske, S.T. 2015. Perceived intent motivates people to magnify observed harms. PNAS Proceedings of the National Academy of Sciences of the United States of America, 112:3599-3605. https://doi.org/ 10.1073/pnas.1501592112

Amundsen, I. 2013. Political Corruption: An introduction to the Issues. Michelsen, Institute of Development Studies and Human Rights: Norway.

Barberis, P. 2012. The managerial imperative: Fifty years' change in UK Public Administration. Public Policy and Administration, 28(4):327-345. https://doi. org/10.1177/0952076712458789

Berth, S. \& Bertok, H. 2012. Professionalism and Ethics: Issues and Practice in Selected Regions. United Nations: New York.

Boris, B. 2009. Corruption, Lobbying and State Capture. Center for Liberal-Democratic Studies (CLDS), School of Law: University of Belgrade.

Colin, L. 1965. What is the Problem about Corruption? The Journal of Modern African Studies, 3(2):215-230. https://doi. org/10.1017/S0022278X00023636

Conrad, H. 2013. Handbook of Public Leadership Theories. Rand-McNally: Chicago.

Echhem, C. 2016. Corruption and AntiCorruption Practices in Human Resource Management in the Public Sector. U4 AntiCorruption Resource Centre: Norway.

Cushman, F. 2013. Action, outcome and value: A dual-system framework for morality. Personality and Social Psychology Review, 17:273-292. https://doi.org/10.1177/108 8868313495594

Encyclopaedia of Applied Ethics. 1998. Consequentialism and Deontology. [Online]. https://bit.ly/3BEVw7M [Accessed 28 February 2021].

Feathers, B. 2014. Bribes without borders: The challenge of fighting corruption in the global context. American University International Law Review, 29(2):287-292. https://doi.org/10.5744/ florida/9780813049106.003.0018

Ganahl, J.P. 2017. Corruption, Good Governance, and the African State: A
Critical Analysis of the Political-Economic Foundations of Corruption in Sub-Saharan Africa. Potsdam University Press: Germany.

Gavisser, F.J. 2018. Rethinking Public Policy: Themes and Perspectives. Journal of Policy and Community Studies, 3(2):255-269.

Grycar, A. \& Prenzler, T. 2013. Understanding and preventing Corruption. Palgrave Mamillan: Basingstoke, UK. https://doi. org/10.1057/9781137335098

Heidenheimer, A.J. 2009. Political Corruption: A Handbook. Transaction Publishers: United Kingdom.

Institute for Security Studies (ISS). 2010. Handbook on comparative analysis SADC. ISS: Pretoria.

Kempfer, J. 2015. Crafting Accountability Policy: Designing Offices for Inspector General, Policy and Society, 2(3):13-27.

Kuye, K.O. \& Mafunisa, M.J. 2003. Responsibility, accountability and ethics: The case for public service leadership. Journal of Public Administration, 38(4):421-437.

Mafunisa, M.J. 2007. Corruption and Service Delivery in the Public Service: The case of Limpopo Province. Journal of Public Administration, 42(3):260-270.

Mail \& Guardian. 2020. Mapping Risk of Factors for the Spread of Covid-19 in South Africa. [Online]. https://mg.co.za/tag/ covid-19/ [Accessed 12 February 2021].

Manyaka, R.K. \& Nkuna, N.W. 2014. The Phenomenon of Corruption in the South African Public Sector: Challenges and Opportunities. Mediterranean Journal of Social Sciences, 5(27):1572-1580. https:// doi.org/10.5901/mjss.2014.v5n27p1572

Mantzaris, E. 2017. Why corruption is SA's biggest security threat? Business Times. [Online]. https://bit.ly/3EyGPFd [Accessed 7 February 2021].

Maroveski, R. 2016. Techniques in Secondary Data Collections: A Beginners' Guide. Victoria: Trafford.

Myint, U. 2000. Corruption: Causes, Consequences and Cures. Asia-Pacific Development Journal, 7(2). [Online]. https://bit.ly/2Y4oIHx [Accessed 7 February 2021]. 
Nwankwo, I., Ananti, Y. \& Madubue, O.T. 2015. Public Bureaucracy: The Neo-Weberian Explanation, Covenant University, Department of Political Science and International Relations: Ogun State, Nigeria.

Organisation for Economic Development and Co-operation (OECD). 2018. Strategic Approach to combating Corruption and Promote Integrity. OECD: United Kingdom.

Prempheh, K. 2008. Governments Target Opposition Parties in Corruption. [Online]. https://bit.ly/3EFn5jn [Accessed 3 March 2021].

Republic of South Africa. 2018-2019. Auditor General's Report. Government Printers: Pretoria.

Republic of South Africa. 2016. Department of Public Service and Administration. Government Printers: Pretoria.

Republic of South Africa. 2013. Country Corruption Assessment Report. Government Printers: South Africa.

Republic of South Africa. 2004. Prevention and Combatting of Corrupt Activities, Act 12. Government Printers: Pretoria.

Republic of South Africa. 1997. Transformation of Public Service Delivery, The Batho Pele Principles. Government Printers: Pretoria.

Republic of South Africa. 1996. The Constitution. Government Printers: Pretoria.

Ruhiiga, T.M. 2009. Costing the impact of corruption on service delivery in South Africa: An exploratory overview. Journal of Public Administration, 44(4):1090-1101.

Sobel, R.S. \& Garret, T.A. 2002. On Rent Seeking and its Opportunity Cost. Public Choice, 5(12):115-136. https://doi. org/10.1023/A:1015666307423

Soliman, H. \& Cable, S. 2011. Sinking under the weight of corruption: Neoliberal reform, political accountability and justice. Current Sociology, 59(6):735-753. https:// doi.org/10.1177/0011392111419748

Thomas, A.J. 1995. Deontology, Consequentialism and Moral Realism. Journal of Business Ethics, 143(2):56-78.
Transparency International. 2014. Corruption Perceptions Index 2015. Transparency International: Berlin.

Touchton, M. \& Wampler, B. 2013. Improving Social Well-being Through New Democratic Institutions. https://doi.org/10.1177/001 0414013512601 [Accessed 5 March 2021].

United Nations. 2015. Sustainable Development Goals, End Inequality and Achieve Sustainable Development for All. Inter Press Service News Agency. [Online]. https://bit.ly/ 3jUOuFU [Accessed 5 March 2021].

Uslaner, E.M. 2017. The Historical Roots of Corruption: Mass, Education, Economics, and State Capacity. Cambridge University Press: Cambridge. https://doi.org/10.10 17/9781108241281

Uys, F. 2012. Ethics and Integrity in the Public Sector. University of Wollongong: New South Wales.

Van der Merwe, J.C. 2016. Making ethics work. In: L.O.K. Lategan \& P. Le Roux (eds.). Business ethics. Tekskor: Bloemfontein. pp. 16-23.

Van der Waldt, G., Khalo, T., Nealer, E., Phutiagae, K., Van der Waldt, C., Van Niekerk, N. \& Venter, A. 2014. Municipal Management: Serving the People. Juta and Company: Cape Town.

Voegtlin, C. \& Scherer, A.G. 2017. Responsible innovation and the innovation of responsibility. Open Access Journal of Philosophy, 19(2015):1-24.

Von Holdt, K. 2019. Why corruption in South Africa is not simply about Zuma and the Guptas. [Online]. https://bit.ly/3w84o4x [Accessed 13 February 2021].

Watkins, E. 2005. Kant and the Metaphysics of Causality. Cambridge University Press: New York. https://doi.org/10.1017/CBO 9780511614217

World Bank. 2014. Evolution of The World Bank's thinking on Governance, Volume 1, World Bank Background Paper. World Bank: Washington, DC. 